\title{
円筒タンクの地震応答解析と模型タンクの加振実験
}

\section{SEISMIC RESPONSE ANALYSIS AND DYNAMIC MODEL TESTS OF CYLINDRICAL TANKS}

\author{
頭井洋*·大谷修**. 新家徹***.西村 昭**** \\ By Hiroshi ZUI, Osamu OHTANI, Tohru SHINKE and Akira NISHIMURA
}

\begin{abstract}
This paper examines the influences of the foundation flexibility and the initial irregularities on the seismic response of cylindrical tanks. A calculation method for describing those behaviors is showed and dynamic shaking table tests are performed. The results of dynamic tests agreed fairly well with the results obtained by numerical calculations. It is concluded that the base fixty conditions will significantly change the seismic response of tanks. It is also concluded that significant high radial accelerations are induced on account of the irregularities, however, stresses induced by the irregularities are less significant.
\end{abstract}

\section{1. まえがき}

平底円筒タンクの地震応答挙動に関しては, 近年数多 くの研究がなされてきており，かなりのことが明らかに されてきた. また，それらの成果を取り入れた耐震設計 基準も出されるに至っている。しかし，これまでの研究 は下部完全固定や円筒部が真円であることを前提にした ものがほとんどでアンカーのない自由支持された円筒夕

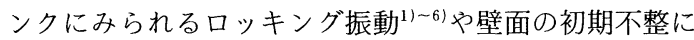

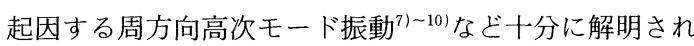
ていない重要課題も多く残されている.

本文は，数値計算および模型実験の両面から下部の支 持条件や壁面の初期不整が円筒タンクの振動特性や地震 応答挙動に及ぼす影響を検討したものである。

数值計算に用いた理論は, 先に報告した下部完全固定 され，地震作用方向に対称な壁面初期不整 $(\cos n \theta)$ を有する円筒タンクの地震応答解析 ${ }^{(0)}$ を，弾性支持や非 対称の初期不整（ $\sin n \theta)$ を有する場合にも適用できる よう発展させたものである.

* 正会員 (株)神戸製鋼所機械研究所要素技術センタ一主任 研究員 ( ₹651 神戸市中央区脇㚱町 1-3-8)

** 正会員 同上, 研究員 (同上)

*** 正会員 工博 同上, 構造強度技術室長 (同上)

**** 正会員 工博 神戸大学教授 工学部土木工学科
数値計算では, 文献 10）では検討しなかった下部支 持条件や上端拘束条件, 入力地震波の応答スペクトル特 性をパラメーターにとり, 容器・液間の連成振動の立場 から初期不整が応答挙動に及ぼす影響を検討した。

また，これまでの実験的研究が，下部固定を対象にし たものが多く77,81,11),14)，弾性支持の実験が数少な( ${ }^{4), 81}$ ところから, 高さ・直径比が 0.875 と 0.53 の 2 種のア ルミ合金製模型タンクを用いて，振動台上に直接固定し た場合と地盤を模擬したゴム上に自由支持した場合の両 方について正弦波加振実験および地震波加振実験を実施 し種々の観点から検討を加えるとともに, 計算值との比 較検討を行った。

\section{2. 理 論解析}

著者らは先にシェル理論と速度ポテンシャル理論に基 づく下部固定され地震作用方向に対称な壁面初期不整を 有する円筒夕ンクの地震応答解析 ${ }^{10)}$ を行い, 容器・液間 の連成振動の立場から初期不整が地震応答挙動に及ぼす 影響を検討した。ここでは文献 10）の解析手法を発展 させて弾性支持の場合や地震作用方向に非対称な壁面初 期不整を有する場合にも適用できる一般化した解析を行 う.

用いた主な仮定は文献 10）とほぼ同様であるが，側 
板下端の条件として，下部完全固定の場合と弾性支持の 両方を扱う. 弾性支持の場合，底板の浮き上がり変形は 生じないものとし，かつ底板に生じる変形は側板直下に 生じる局部変形が主体で底板の大部分は水平を保つと仮 定する．解析の手順は，文献 10）之同様壁面に初期不 整を有する場合の動液圧を速度ポテンシャルで表示し， これと初期不整がない場合の固有振動解析より得られる 容器・液体連成系の固有振動数, 振動モードとを用いて 壁面に任意の初期不整を有する円筒タンクの地震応答解 析の基礎式を導く。

Fig. 1 の座標系で初期不整を含むタンク半径は, 平均 半径を $a_{0}$ として次のように表わされる.

$$
a=a_{0}\left[1+\sum\left\{\varepsilon_{a n} f_{a n}(x) \cos n \theta+\varepsilon_{b n} f_{b n}(x) \sin n \theta\right\}\right]
$$

ここで, $\varepsilon_{a n} \ll 1,\left|f_{a n}(x)\right| \leqq 1, \quad \varepsilon_{b n} \ll 1,\left|f_{b n}(x)\right| \ll 1$, で ある．速度ポテンシャルを導くにあたり応答解析を円周 方向各次振動モードの重祖合せで行うため式（1）の右 辺第 2 項のうち $n$ 次成分のみを取り出す. 速度ポテン シャル $\phi$ を初期不整がない場合の速度ポテンシャル $\phi_{0}$ と初期不整による付加的な速度ポテンシャル $\phi_{c}$ と $\phi_{s}$ と の和として次のように表わす。

$$
\begin{aligned}
\phi(r, \theta, x, t)= & \phi_{0}(r, \theta, x, t)+\varepsilon_{a n} \phi_{c}(r, \theta, x, t) \\
& +\varepsilon_{b n} \phi_{s}(r, \theta, x, t) \cdots \cdots \cdots \cdots \cdots \cdots
\end{aligned}
$$

文献 10）と同様一次のパータベーション法を適用し, 式（2）の速度ポテンシャルを導くと次のようになる。

$$
\begin{aligned}
\phi_{0}(r, \theta, x, t)= & \sum_{i=0} A_{i}(t) \cdot I_{1}\left(\lambda_{i} \frac{r}{H}\right) \cdot \cos \left(\lambda_{i} \frac{x}{H}\right) \\
& \cdot \cos \theta \cdots \cdots \cdots \cdots \cdots \cdots \cdots \cdots \cdots \cdots \cdots \cdots \cdots \cdots \cdots \cdots \cdots \cdots \cdots \cdots \cdots \\
\phi_{c}(r, \theta, x, t)= & \sum_{i=0} B_{i}(t) \cdot I_{n-1}\left(\lambda_{i} \frac{x}{H}\right) \cdot \cos \left(\lambda_{i} \frac{x}{H}\right) \\
& \cdot \cos (n-1) \theta+\sum_{i=0} \tilde{B}_{i}(t) \cdot I_{n+1}\left(\lambda_{i} \frac{x}{H}\right) \\
& \cdot \cos \left(\lambda_{i} \frac{x}{H}\right) \cdot \cos (n+1) \theta \cdots \cdots \cdots(4)
\end{aligned}
$$

$$
\begin{aligned}
\phi_{s}(r, \theta, x, t)= & \sum_{i=0} C_{i}(t) \cdot I_{n-1}\left(\lambda_{i} \frac{x}{H}\right) \cdot \cos \left(\lambda_{i} \frac{x}{H}\right) \\
& \cdot \sin (n-1) \theta+\sum_{i=0} \tilde{C}_{i}(t) \cdot I_{n+1}\left(\lambda_{i} \frac{x}{H}\right) \\
& \cdot \cos \left(\lambda_{i} \frac{x}{H}\right) \cdot \sin (n+1) \theta \cdots \cdots \cdots(5
\end{aligned}
$$

ここで, $A_{i}(t), B_{i}(t), \tilde{B}_{i}(t)$ は文献 10) に与えている ものと同様である. また $C_{i}(t), \tilde{C}_{i}(t)$ は， $B_{i}(t), \tilde{B}_{i}(t)$ の $f_{a n}(x)$ を $f_{b n}(x)$ に置換したものである.

動液圧 $P(r, \theta, x, t)$ は, 式 $(2)$ を時間 $t$ で偏微分 した次式で与えられる。

$\boldsymbol{P}(r, \theta, x, t)=-r_{L} \partial \phi(r, \theta, x, t) / \partial t$

式 (4) （6) より $\cos n \theta$ の初期不整により $\cos (n$ $-1) \theta$ と $\cos (n+1) \theta$ 成分の動液圧が励起され, $\sin n \theta$

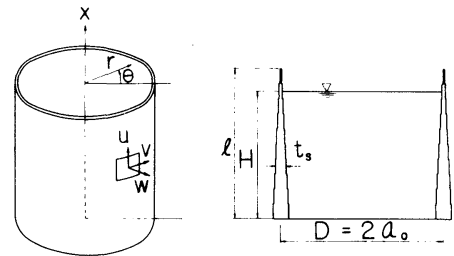

Fig. 1 Cylindrical Tank and Coordinate System.

成分の初期不整により $\sin (n-1) \theta$ と $\sin (n+1) \theta$ 成分 の動液圧が励起されることがわかる。

初期不整のない円筒タンクの容器・液体連成系が調和 振動しているとき, 円筒シェルの変位・断面力の軸方向 座標 $x$ に関する一次方程式は次のように得られる ${ }^{101}$.

$$
\frac{d}{d \bar{x}} \boldsymbol{Z}=\boldsymbol{A} \boldsymbol{Z}
$$

ここに, $\boldsymbol{Z}$ は変位・断面力の軸方向振動モードを表わ す関数， $\boldsymbol{A}$ は $8 \times 8$ の係数マトリックスである.

式（7）には，静液圧による初期方向膜力や動液圧に よる付加質量が考慮されている.

下端の境界条件は，次式で与えられる.

下部完全固定の場合

$$
u=v=w=d w / d x=0
$$

弾性支持 (Fig. 2) の場合

$$
\begin{aligned}
& v=w=0,-u=w_{B 1}=w_{B 2} \\
& d w / d x=w_{B 1}^{\prime}=w_{B 2}^{\prime} \\
& M_{r_{1}}-M_{r_{2}}-M_{x}=0 \\
& Q_{r 1}-Q_{r 2}-N_{x}=0
\end{aligned}
$$

式 (9) で $w_{B}, w_{B}^{\prime}$ 等は底板の鉛直たわみおよびたわ み角である． $w_{B}, w_{B}^{\prime}, M_{r}, Q_{r}$ に関する一般解は, 弾 性支承上の円板に関する微分方程式の解として得られ $3^{5)}$.

これらと式（9）より側板下端の境界条件が得られる. 簡単のため,アニュラー板の張り出し部がない場合につ いて示すと次のようになる.

$$
\left\{\begin{array}{c}
u \\
d w / d x
\end{array}\right\}=\frac{1}{2 D_{a} \beta^{2}}\left[\begin{array}{cc}
-1 & 1 / \beta \\
2 \beta & -1
\end{array}\right]\left\{\begin{array}{c}
M_{x} \\
N_{x}
\end{array}\right\}
$$

ここに, $\beta=\sqrt[4]{k_{v} / D_{a}}, D_{a}=E t_{a}^{3} / 12\left(1-\nu^{2}\right)$ である. $t_{a}$ はアニュラー板の板厚である.

また上端の境界条件は，すべての断面力を 0 としてい る.さらに上端拘束の場合これに加えて次の境界条件式 を用いている。

$$
k=1: v=w, k \geqq 2: v=w=0
$$

式（7）を式（8)～(11）の境界条件のもとに解けば, 固有振動数と振動モードを求めることができる ${ }^{10}$.

初期不整を有する円筒タンクに水平地震動 $u_{\mathrm{g}}$ が作用 する場合の側板変位の応答を，初期不整がない場合の連 成系振動モードを用いて次式で表示する。 


$$
\begin{aligned}
u= & \sum_{k=1} \sum_{s=1}\left\{\left(f_{1}^{*}\right)_{k s} q_{k s} \cdot \cos k \theta\right. \\
& \left.+\left(\tilde{f}_{1}^{*}\right)_{k s} \tilde{q}_{k s} \sin k \theta\right\} \\
v= & \sum_{k=1} \sum_{s=1}\left\{\left(f_{2}^{*}\right)_{k s} \cdot q_{k s} \cdot \sin k \theta\right. \\
& \left.+\left(\tilde{f}_{2}^{*}\right)_{k s} \tilde{q}_{k s} \cos k \theta\right\} \\
w= & \sum_{k=1} \sum_{s=1}\left\{\left(f_{3}^{*}\right)_{k s} \cdot q_{k s} \cdot \cos k \theta\right. \\
& \left.+\left(\tilde{f}_{3}^{*}\right)_{k s} \tilde{q}_{k s} \sin k \theta\right\}
\end{aligned}
$$

ここに, $\left(f_{1}^{*}\right)_{k s} \cdots,\left(\tilde{f}_{1}^{*}\right)_{k s} \cdots$ はそれぞれ周方向 $k$ 次, 軸 方向 $s$ 次の変位 $u, v, w$ の対称振動乇一ド, 逆対称振 動モ一ドを表わしている. また $q_{k s}, \tilde{q}_{k s}$ はそれぞれ対応 する一般座標である。

文献 10）と同様の所論より式（6), (12) を Lagrange の運動方程式に代入して整理すると, 地震応 答の基礎式が各次モードごとに得られる.

\section{3. 数值計算}

\section{（1）側板直下の基礎地盤の剛性低下による固有振動 数の低下}

藤田は2)，底板全体が弾性ばねに支持されている円筒 タンクのロッキング振動解析を, FEM により行ってい る. 著者らは, 同様の問題を側板直下の底板の局部变形 が支配的としてはりモデルで解析した ${ }^{11}$.

ここでは，このような側板直下の底板の局部変形によ り生じる部分ロッキングについて本文 2. の計算手法を 用い，地盤のばね定数をパラメーターにとり固有振動数 を計算した。計算モデルは文献 2) で用いられたモデル と同じで $H / D=0.5, t_{s} a=0.001, t_{a} / t_{s}=0.5$ とした. Fig. 3 に計算結果を示す. 縦軸に無次元化した振動数, 横軸に無次元化した地盤のばね定数を示している.

Fig. 3 には，FEM による藤田の計算値を○で示した。 また文献 1) のはりモデルによる計算值を破線で示した。

Fig. 4 は, 本文の手法による振動モードを示している. 本文の手法による計算值は，文献 1) のはり理論による 計算値および文献 2) の藤田による FEM 計算値とよく 一致している. Fig. 4 の振動モ一ドも文献 2) の振動モ一 ドとよく一致しており, 弾性支持の底板の振動モードは 側板直下に集中している. また, 円筒タンクの固有振動 数は側板直下の基礎の剛性が低下するにつれ下部固定の 場合よりかなり低下する.

\section{（2）壁面の初期不整が地震応答挙動に及ぼす影響}

文献 10) では, Clough の実験モデル ${ }^{71,8)}$ を用いて壁 面の初期不整の周方向波数, 高さ方向形状および液深 · 直径比をパラメーターにとり EL Centro NS 波を入力 地震波として初期不整の影響を論じた。その結果, 初期 不整の大きさを表わす無次元值 $\varepsilon$ (初期不整最大值の半 径に対する比）を同じとすると， $H / D$ の小さな偏平な

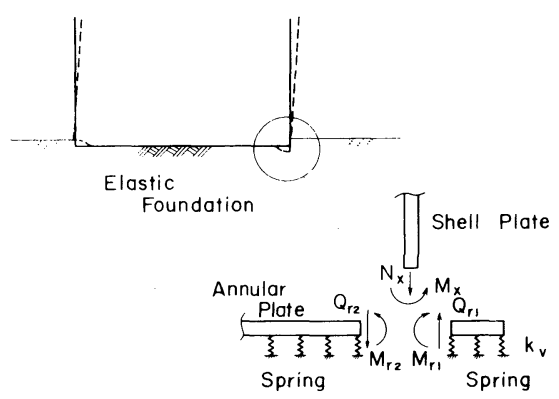

Fig. 2 Force and Moment Resultants of Bottom Corner (Elastic Support).

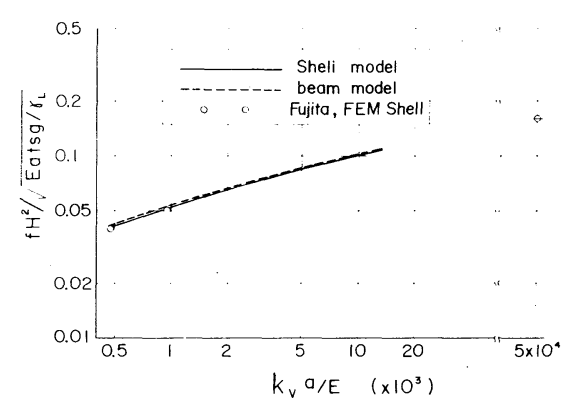

Fig. 3 Decreasement of Natural Frequencies due to Foundation Flexibility.

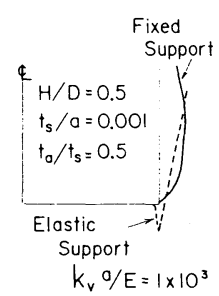

Fig. 4 Vibrational Modes of Shell Plates.

タンクほど周方向高次の花びら振動が励起されやすく, 側板下端の軸方向膜力が増大すること, 偏平なタンクで は高次のものが励起されやすいこと, $\cos n \theta$ の初期不 整により励起される $\cos (n-1) \theta$ と $\cos (n+1) \theta$ の応答 のうち $\cos (n-1) \theta$ の応答の方がかなり大きいこと, ま たその忘答值は $\varepsilon$ に比例することなどを明らかにした.

ここでは，文献 10）では検討しなかった，下端支持 条件, 上端拘束条件および入力地震波の周波数特性をパ ラメーターにして, 初期不整が応答挙動に及ぼす影響を 検討する. 偏平なタンクで花びら振動が大きく励起しや すいことと小型のタンクほど $\varepsilon$ が大きくなりやすいと 考えられることから, 直径 $20 \mathrm{~m}$, 高さ $11 \mathrm{~m}$, 液深 $10 \mathrm{~m}$, 側板板厚 $10 \mathrm{~mm}$ の小型タンクを計算モデルに用いた. 入力地震波は Fig. 5 の応答スペクトル ${ }^{121}$ を満足する模擬 地震波を文献 13）の手法を用いて作成したものを用い た. 前述したように $\sin n \theta$ の初期不整により $\sin (n-1)$ 


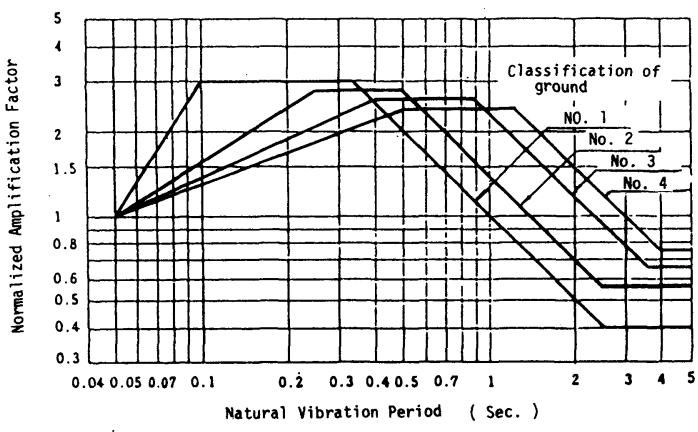

Fig. 5 Response Spectra for Seismic Design.

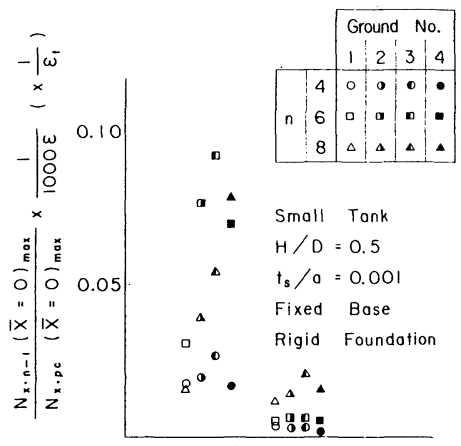

Open Top Roof Top

Fig. 6 Effect of the Initial Irregularities Upon the Axial Membrane Force (Fixed Base).

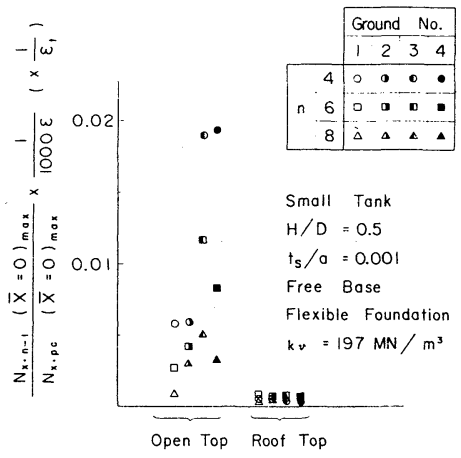

Fig. 7 Effect of the Initial Irregularities Upon the Axial'Membrane Force (Free Base).

$\theta$ と $\sin (n+1) \theta$ の成分を有する応答が励起するが, $\sin$ $k \theta$ の固有振動数および振動モードは, $\cos k \theta$ のそれら とほとんど一致することから，その応答性状も $\cos k \theta$ の応答性状とほとんど同じである.したがって以下 $\cos$ $n \theta$ の初期不整のみを対象とする. 花びら型振動の応答 性状のうち耐震設計上重要なものは応力の応答值であ り, ここでは側板の座屈や象の脚型張り出しに関係する 側板下端における軸方向膜力 $N_{x}$ について示す. Fig. 6 に下部完全固定の，Fig. 7 に弾性支持の場合の結果を示
す.

縦軸は, 文献 10）と同じく, 真円の場合の応答值に 対する比で表示している.この計算モデルでは $a / t_{s}=$ 1000 であるので, $\varepsilon_{t}=1000 \varepsilon$ となる. Ground No.は, Fig. 5 の地盤種別を表わしている. 初期不整は高さ方向 一定とし, $\varepsilon_{n} \cdot \cos n \theta$ とした. Fig. 6,7 より次のような ことがわかる．真円の場合に生じる $N_{x . p c}$ に対する周方 向高次の $N_{x, n-1}$ の比は, 弾性支持の場合, 下部固定の場 合より小さくなり, 固定屋根の場合, オープントップの 場合に比べかなり小さくなる. Fig. 7には示さなかった が $n=2,3$ のときの $N_{x \cdot n-1}$ は, $n=4$ の $N_{x . n-1}$ より小さ くなる. 実際の円筒タンクでは製作施工要領等で初期不 整の大きさは, $\varepsilon=0.001$ 程度以下となるようにおさえ られている. 花びら振動が大きくなるオープントップで 下部固定の偏平なタンクにおいても $\varepsilon=0.001$ として周 方向高次の $N_{x}$ は, 高々真円タンクの $N_{x . p c}$ の $10 \%$ 程度 であるので, 初期不整が $\varepsilon=0.001$ より相当大きくなる 場合を除き，耐震設計上周方向高次の応答をそれほど重 要視する必要はないと考えられる.

\section{4. 模型タンクの振動台加振実験}

\section{（1）模型タンクの諸元と製作方法}

容器・液体連成系の円筒タンク縮小モデルの相似則を 満足させるには, 重力の加速度, 液比重を同じものにし なければならないという制約のもとでは，材料の弾性係 数の比を寸法縮小率に等しくする必要がある ${ }^{81}$. 樹脂材 料を用いるとこれが可能になるが，ひずみ計測を精度よ く行うことが難しい．そこで本実験では計算方法の検証 に重点をおいて，直径 $50 \mathrm{~m}$ 程度の鋼製円筒タンクを想 定し，材料にはアルミ合金 Al 5052 を用い，利用した振 動台に設置可能で最大となる直径 $1.6 \mathrm{~m}$ の模型タンク を用いて実験を行った. Fig. 8 に模型タンクの諸元を示 す.側板は一枚板を 1 か所で突き合せ溶接し, 底板との 接合はスポット溶接と接着剤によった。また側板上部の 補強アングルと側板との接合にもスポット溶接を用い た。

\section{（2）実験方法}

内容液には水を用い, 側板下部の支持条件として振動
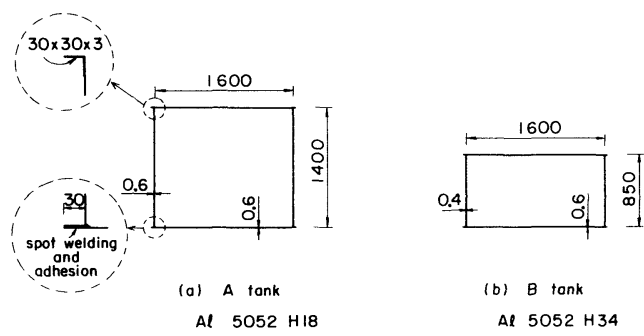

(b) B tonk Al $5052 \mathrm{H} 34$

Fig. 8 Dimensions of Tank Models. 
Table 1 Test Cases.

\begin{tabular}{|c|c|c|c|c|}
\hline $\begin{array}{l}\text { Tank } \\
\text { Name }\end{array}$ & $\begin{array}{l}\text { Tank } \\
\text { Shope }\end{array}$ & $H / D$ & $\begin{array}{l}\text { Support } \\
\text { Condition }\end{array}$ & $\begin{array}{l}\text { Method of } \\
\text { Excitation }\end{array}$ \\
\hline \multirow{5}{*}{ A - Tank } & & \multirow{4}{*}{0.8} & Fixed Base & Sinusoidal Wove \\
\hline & & & Rigid Foundation & El Centro NS I/8 \\
\hline & \multirow{3}{*}{$\begin{array}{l}\sigma / t_{s}=1333 \\
t_{0} / t_{s}=1.0\end{array}$} & & Free Base & Sinusoidal Wave \\
\hline & & & Flexible Founda & El Centro NS I/8 \\
\hline & & 0.5 & Fixed Rigid & El Centro NS I/8 \\
\hline \multirow{4}{*}{ B - Tank } & \multirow{4}{*}{$\begin{array}{l}\ell / D=0.53 \\
a / t=2000 \\
t_{0} / t_{s}=1.5\end{array}$} & \multirow{4}{*}{0.5} & \multirow{2}{*}{$\begin{array}{l}\text { Fixed Base } \\
\text { Rigid Foundation }\end{array}$} & Sinusoidal Wave \\
\hline & & & & El Centro NS I/8 \\
\hline & & & \multirow{2}{*}{$\begin{array}{l}\text { Free Base } \\
\text { Flexible Founda. }\end{array}$} & Sinusoidal Wove \\
\hline & & & & EI Centro NS I/8 \\
\hline
\end{tabular}

台上に直接固定した場合と厚さ $50 \mathrm{~mm}$, 硬度 50 のゴム 上に自由支持した場合の 2 通りについて実験を行った。 加振方法として, 基本的な振動特性を求めるための正弦 波加振実験と地震時の応答挙動を調べるための地震波加 振実験之を行った。加振方向は水平一方向である.

Table 1 に実験系列を示す. 用いた振動台は当社機械研 究所の $10 \mathrm{t}$ 油圧型振動台である. 地震波には El Centro NS 波を時間軸に $1 / 8$ 圧縮したものを用いた．時間縮尺 を $1 / 8$ とした理由は, 模型タンクの基本固有周期が想定 した実タンクの基本固有周期の約 $1 / 8$ となり固有周期と 地震波のスペクトル特性との対応を実構造物のそれと同 一条件にするためである. 計測項目は以下のとおりであ る. 花びら振動の影響をみるため側板中央部の法線方向 加速度を周方向各位置で, ひずみゲージ式加速度計によ り測定した．動液圧は，加振方向軸 $\left(\theta=0^{\circ}\right)$ において 側板中央部求よび下部の 2 点につき，ひずみゲージ式圧 力計により測定した．また $\theta=0^{\circ}$ の位置において, 側板 中央部と下部の各位置に 2 軸ゲージを貼付して動ひずみ を測定した．各センサーからの信号を動ひずみ計を介し てデータレコーダーに同時収録した．正弦波加振の加速 度は十分な計測精度が得られ, かつ共振点で応答值がセ ンサーの上限值を越えないよう $20 \mathrm{gal}$ とした。一方, 地震波加振の入力加速度は $100 \mathrm{gal}$ とし, 各試験条件で 入力信号に対する台加速度の伝達関数を求め, この特性 を打ち消すように目標を補正して，再現精度を上げた。 Photo 1 に実験状況を示す.

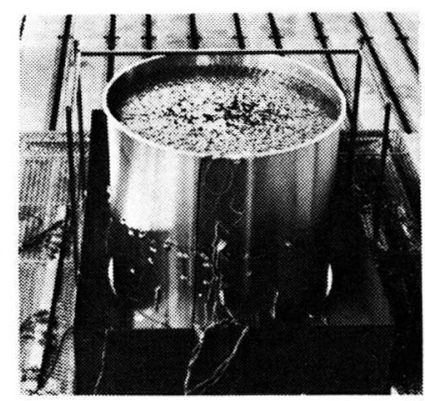

Photo 1 Dynamic Test.
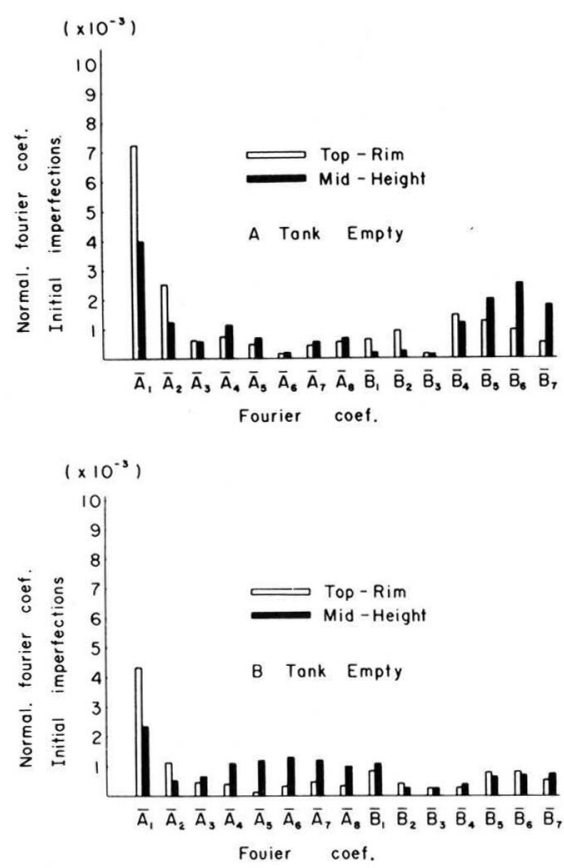

Fig. 9 Normalized Fourier Coefficients of Radial Imperfections of Tank Models.

\section{（3）空時の模型タンク壁面の初期不整}

加振実験に先だって測定した空時の模型タンクの壁面 初期不整の測定結果を Fig. 9 に示す. Fig. 9 の $\bar{A}_{n}, \bar{B}_{n}$ は, 測定結果をFourier 分析し, $\cos n \theta, \sin n \theta$ の各 係数を半径で正規化したものを示している. Fourier 分 析する前の初期不整の最大值は, 半径比で A タンク 0.0095, B タンク 0.0033 であった。後述するように, 周方向波数 $n$ が小さい低次の初期不整成分は，液を満 たしてもそれほど減少せず残存しているものと考えられ る.

\section{(4) 実験結果とその考察}

a) 正弦波加振実験

Fig. 10 に A, B 両タンクの下部固定および自由支持 それぞれの側板中央部法線方向加速度 $\left(\theta=0^{\circ}\right)$ の下端 に対する応答倍率および位相遅れを示す．いずれも台上 加速度に対する応答倍率を示している. Fig. 10 には, 2.に示したシェル理論による計算值を破線で示した．真 円の円筒タンクに対する計算値で，減衰定数は下部固定 に対し 0.02 ，自由支持に対し 0.04 とした. 自由支持の 場合は，側板直下の底板の局部変形によるロッキングを 伴う場合の計算值である. 基礎のばね定数は静的載荷試 験より求めた $k_{v}=59 \mathrm{MN} / \mathrm{m}^{3}$ とした. なお, 文献 1) の はり理論による計算値もシェル理論による計算値とほと んビ一致する.

実験より求まる応答倍率曲線は，下部固定の場合周方 

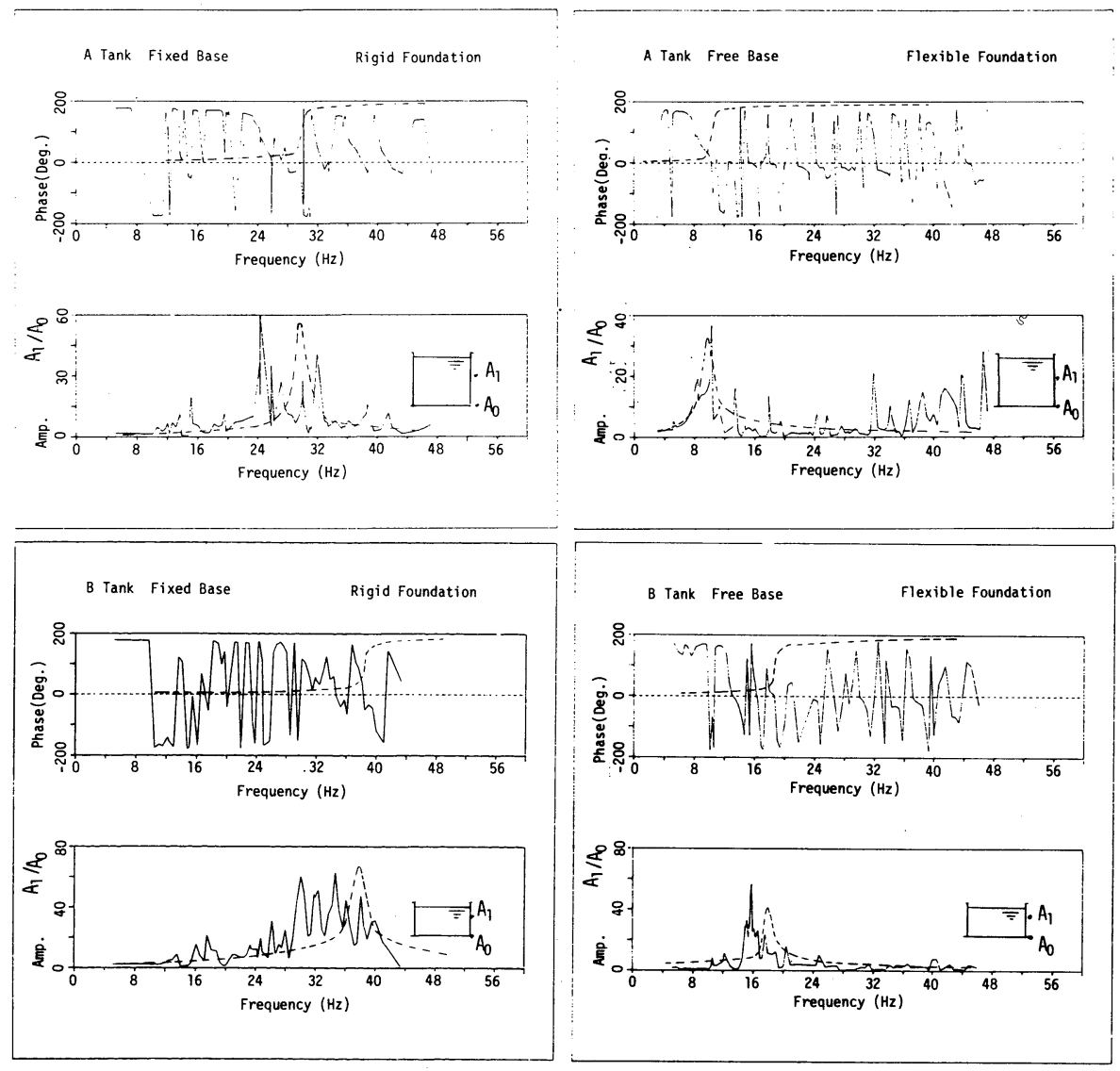

Fig. 10 Frequency Responses of Tank Models.

向高次の共振モードを含む多くのピークがみられ, 最大 の応答值を与える卓越振動数は計算値のそれ（基本固有 振動数）より $20 \%$ 程度小さくなっている. 一方, 撓性 基礎に自由支持した場合の実験より求まる応答曲線には 明瞭な卓越振動数が存在し, その值は計算による卓越振 動数ともよく一致している. また自由支持の場合の卓越 振動数の $1 / 2$ 以下となりかなり小さくなっている. 最大 の応答值を与える卓越振動数における側板中央部の周方 向各位置の法線方向加速度は Fig. 11 に示すように $\cos$ $\theta$ 分布とはならなかったが, これは $\cos \theta$ 成分の応答値 に壁面の初期不整に起因する花びら型振動の応答值が重 なったためと考えられる.

下部固定の実験より得られた基本振動数が, 下部完全 固定の計算値を若干下回った理由は, 本実験の場合次の ように考えられる. 側板下端を振動台に固定する際, 強 制変位により側板下端と接着剤の一部にはく離が生じ, シリコン系の充填剤で応急補修した。しかし強度が十分 でなく転倒モーメントにより側板下端がわずかであるが 浮き上がった可能性が高い。このため部分ロッキングが 生じ下部完全固定の条件を満足させることができなかっ

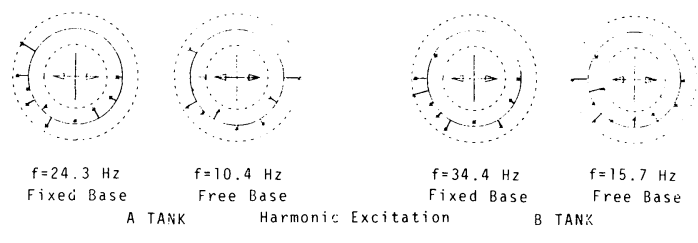

Fig.11 Circumferential Modes of Radial Accelerations on Mid-Height.

たのではないかと考えられる. Fig.10より次のような ことがいえよう.

剛基礎上に固定支持された場合，花びら型振動が励起 されやすく，撓性基礎に自由支持された場合一次のロッ キング振動が支配的で花びら型振動の影響は小さい。こ れらは3.で得た数值計算の結果と一致している. 自由 支持された場合, 入力加速度が大きくなると転倒モーメ ントにより浮き上がりが生じる ${ }^{4), 61,8)}$. 本実験では, 入 力加速度を $20 \mathrm{gal}$ 亡低くおさえたため, 明瞭な浮き上 がり挙動は観測されなかった. Fig. 10 に示すように, 浮き上がりを無視した線形のロッキング解析より求まる 固有振動数と実験值とがよく一致していることからも， 

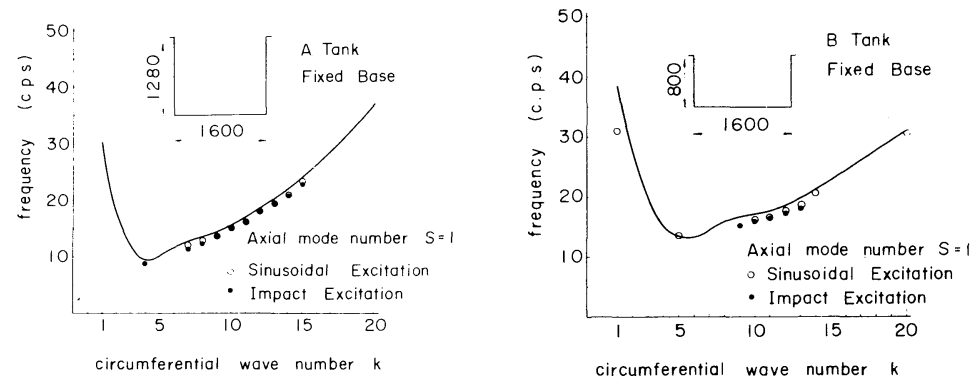

Fig. 12 Natural Frequencies of Tank Models.

本実験は浮き上がり効果を無視し得る線形の範囲によど まったものと考えられる.

Fig. 12 にはA，B両タンクの下部固定の場合の周方 向各波数における固有振動数の実測値と計算值を示す. ○印は正弦波加振実験における周方向各位置の法線方向 加速度を Fourier 分析し，台上加速度と同じ成分をもつ 振動数成分の振幅亡位相より求めた固有振動数である. また・印は打撃加振実験のモ一ダル解析より求めた固有 振動数である.モーダル解析のソフトには SMS 社の モーダル 3.0 を用いた。 2. の手法より求めた真円夕ン クの固有振動数が実線で示されている. Fig. 12 より各 周方向波数における固有振動数の計算值は正弦波加振実 験あるいは打撃加振実験より求めた実験值とよく一致し ていることがわかる. 模型タンクには初期不整が存在し ていることから固有振動性状に及ぼす初期不整の影響は 小さいといえよう.

b) 地震波加振実験

Fig. 13 に A タンクの下部固定および自由支持の場合 のひずみおよび動液圧の時刻歴応答波形の例を示す。い ずれも 1 自由度系の応答波形に近く, 特定の振動数で応 答している様子がみられる. Table 2 に, 各実験条件に おけるひずみ波形をFourier 変換して求めた卓越振動数

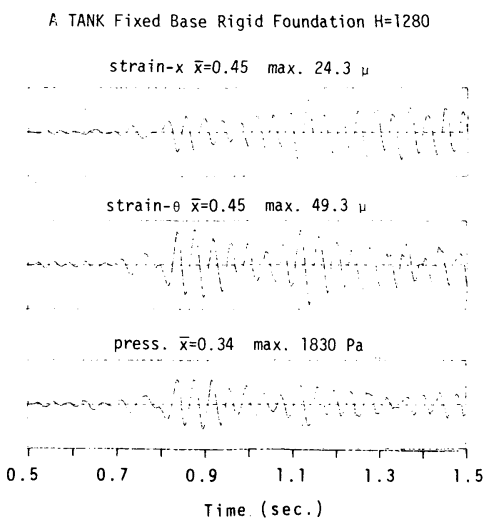

Table 2 Fundamental Natural Frequencies of Tank Models.

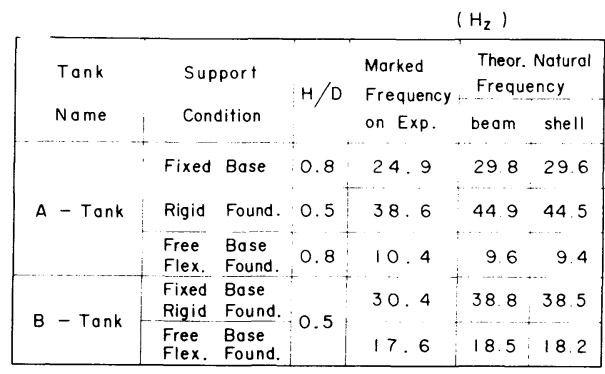

を示した. Table 2 の卓越振動数は, 正弦波加振実験に おける卓越振動数とほぼ一致している. Table 2 には, 2. および文献 1) の手法より求めた基本固有振動数の計 算值も併記した. 自由支持の場合は実験における卓越振 動数は計算による基本振動数とほぼ一致している。一方 固定支持の場合は計算による基本振動数に比べ実験にお ける卓越振動数は $20 \%$ 程度小さくなっている.この理 由は先に述べたように実験では下部完全固定の条件を満 足させることができなかったためと考えられる.

Table 3，4 にはそれぞれ A，B両タンクで観測され た各応答最大值と計算による応答最大值の比較を示し た.いずれも $\theta=0^{\circ}$ における值である．計算では，はり

A TANK Free Base Flexible Foundation $H=1280$

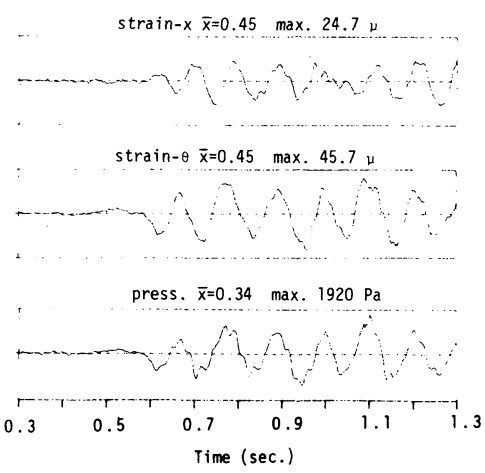

Fig. 13 Time Histories of Shell Strains and Pressures (Input El Centro NS 1/8). 
Table 3 Maximum Values of Acceleration, Pressure and Stress (A Tank).

\begin{tabular}{|c|c|c|c|c|c|c|c|c|c|}
\hline \multirow[t]{2}{*}{$\begin{array}{l}\text { Base } \\
\text { Condi- } \\
\text { tion }\end{array}$} & \multirow{2}{*}{$\begin{array}{l}\text { Water } \\
\text { Depth } \\
\mathrm{H}(\mathrm{mm}) \\
(\mathrm{H} / \mathrm{D})\end{array}$} & \multirow[t]{2}{*}{$\begin{array}{l}\text { Type } \\
\text { of } \\
\text { Data }\end{array}$} & \multirow{2}{*}{$\begin{array}{l}\text { Acce. } \\
(9 \circ 1) \\
\bar{X}=0.5\end{array}$} & \multicolumn{2}{|c|}{$\begin{array}{c}\text { Dyna. Press. } \\
(\mathrm{Pa})\end{array}$} & \multicolumn{2}{|c|}{$\begin{array}{l}\text { Shell Stress } \\
\bar{x}=0.05\end{array}$} & \multicolumn{2}{|c|}{$\begin{array}{l}(M P a) \\
\bar{x}=0.45\end{array}$} \\
\hline & & & & $\bar{x}=0.05$ & $\bar{x}=0.34$ & $\sigma_{x}$ & $\sigma_{\theta}$ & $\sigma_{x}$ & $\sigma_{\theta}$ \\
\hline & 800 & observed & 1190 & 1170 & 1350 & 0.84 & 1.86 & 0.28 & 2.40 \\
\hline & & pre- beam & 276 & 1120 & 1190 & 0.65 & 1.31 & 0.02 & 0.96 \\
\hline Fixed & $(0.5)$ & dicted shell & 333 & 1180 & 1280 & 0.68 & 1.18 & 0.03 & 1.08 \\
\hline Rigid & & observed & 657 & 1510 & 1830 & 2.38 & 1.73 & 0.74 & 3.26 \\
\hline & & pre - beam & $283^{\circ}$ & 1390 & 1520 & 2.02 & 1.85 & 0.52 & 2.17 \\
\hline & 10.8 & dicted shell & 325 & 1380 & 1630 & 2.12 & 1.58 & 0.48 & 2.30 \\
\hline Free & 1280 & observed & 356 & 1450 & 1920 & 2.44 & 1.76 & 0.85 & 2. 97 \\
\hline & $(0.8)$ & $\begin{array}{l}\text { pre - beam } \\
\text { dicted shell }\end{array}$ & $\begin{array}{l}319 \\
323\end{array}$ & $\begin{array}{r}1480 \\
+1470\end{array}$ & 1760 & 2.26 & 1.97 & 0.65 & 2.46 \\
\hline
\end{tabular}

Table 4 Maximum Values of Acceleration, Pressure and Stress (B Tank).

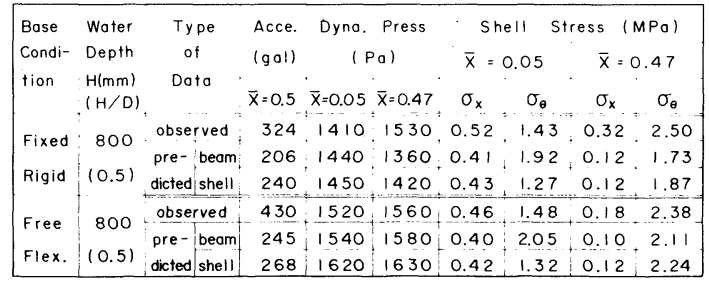

理論, シェル理論ともに真円の円筒タンクを対象とし基 本振動のみを考慮して各試験条件で計測した台上加速度 を入力として用いた。減衰定数は, 下部固定 0.02 , 自 由支持 0.04 とした. Table 3, 4 の計算応力は膜応力を 示しており, 実測応力は外側の表面応力すなわち膜応力 とシェルの曲げ応力の両者を含んだ值となっている. 真 円タンクに対する測定位置の曲げ応力計算值は膜応力に 比べ無視し得る程度に小さい.はり理論とシェル理論に よる計算值を比較すると全般的によく一致している．側 板下端の $\sigma_{\theta}$ にやや大きな相違がみられる理由は，はり 理論では下端における側板法線方向変位の拘束の影響を 考慮していないためである. Table 3，4より実測值亡 計算値それぞれの最大応答値を比較すると以下のようで ある。

動液圧については，実測値と計算值はほぼ一致してお

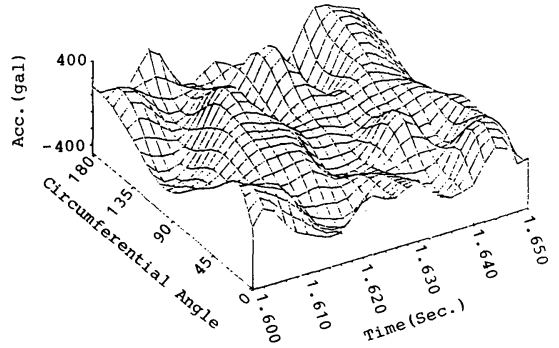

A TANK Fixed Base Rigid Foundation $\mathrm{H}=1280$
り側板下部の軸方向および周方向応力についても下部固 定で特に $H / D$ が小さい場合に実測值の方が 10〜30\% 大きくなっているが，実測值と計算値はよい対応を示し ている。一方, 側板中央部における法線方向加速度の実 測值は計算值を大きく上回っており，側板中央部の応力 についても実測值は計算値より大きくなっている．また 下部固定の場合および $H / D$ の小さい場合にその傾向が 著しい.この理由は, 初期不整に起因する花びら振動が 大きく励起されているためで, 側板中央部の法線方向加 速度と応力にその影響が特に大きく現われたためであ る. Fig. 14 に側板中央部法線方向加速度実測值の展開 図を示したが，各時刻における周方向分布は, $\cos \theta$ 分 布とならず花びら振動が生じていることがわかる。

2. に示した初期不整を有する円筒夕ンクの容器・液体 連成系の地震応答解析によると, Fig. 9 の初期不整が静 液圧下でほとんど残っているとすると側板下端における 高次の $N_{x}$ が真円の場合の $N_{x}(\cos \theta$ 成分 ) の 10 20\% 生じることになり，側板下端の応力が真円の場合の計算 值を $10 〜 30 \%$ 上回った点についてはほぼ説明がつく. しかし, 容器・液間の連成振動の観点のみでは, 側板中 央の加速度や応力についても周方向高次の応答值は真円 の場合の計算值の $10 \%$ 程度にしかならず，実測值が真 円を仮定した計算値の 2 倍以上にもなっている点の説明 はつかず，初期不整に起因する花びら振動を生じさせる 別の原因を考える必要がある。

空時の初期不整は液を満たすことによりその内圧のた め減少し,さらに動液圧が加わるとその一部は回復もし くはさらに減少する.この点に関しては, $\mathrm{Niwa}^{14)}$ ある

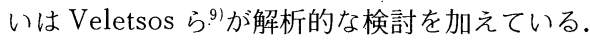

Veletsos らは ${ }^{9)}$, 静液圧および動液圧 $(\cos \theta$ 成分のみ) をそれぞれ高さ方向，周方向に一様な内圧に置換し，一 様外圧による座屈荷重を用いてこの問題を検討してい る.ここでも, Veletsos らと同様の取扱いにより Fig. 9 に示した空時の初期不整の静液圧および動液圧による変 動の程度について検討してみる。

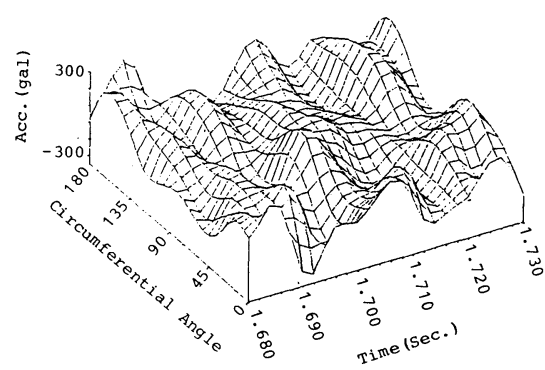

B TANK Fixed Base Rigid Foundation $\mathrm{H}=800$

Fig. 14 Isometric Plot of Radial Accelerations on Mid-Height. 
高さ方向 $\sin (\pi x / l)$, 周方向 $\cos n \theta$ の初期不整は, 一様内圧 $P_{0}$ により

$$
(L F)_{n}=\frac{P_{0} /\left(P_{c r}\right)_{n}}{1+P_{0} /\left(P_{c r}\right)_{n}}
$$

で与えられる係数分だけ減少する ${ }^{91}$. 式 (13) は, 初期 不整と内圧によって生じる变位を二重 Fourier 級数で表 示しこれをDonnel 方程式に代入することにより導く ことができる ${ }^{15)} .\left(P_{c r}\right)_{n}$ は初期不整と同じモ一ドをもつ 一様外圧による古典座屈理論値である. 式 (13) を用い て A, B両タンクの満液下の $(L F)_{n}$ を計算すると Table 5 のようになる. Table 5 より $H / D=0.8$ の ンクでは $n=4$ 以下の初期不整は液を満たした後もほと んど残り， $n \geqq 8$ の初期不整はほとんど消失することに なる. 一方 $H / D=0.5$ の B タンクでは $n=6$ 以下の初 期不整は液を満たした後もほとんど残り， $n=9$ で $60 \%$ 程度減少することになる。一方, 動液王についても真円 タンクの応答值として得られる $\cos \theta$ 成分の動液圧 $P_{d 1}$ を支配的と考えると, 水平方向加振下の液圧 $P(\theta)$ は

$$
P(\theta)=P_{0}+P_{d_{1}} \cos \theta
$$

で表わされ, 動液圧により引き起こされる初期不整の変 動分 $w_{p}$ は次式で与えられる ${ }^{9)}$.

$$
w_{p}=\varepsilon_{n} a_{0}\left[(D L F)_{n \theta}-(L F)_{n}\right] \cos n \theta
$$

$(D L F)_{n \theta \theta}$ は, 式 (13) の $P_{0}$ に式 (14) の $P(\theta)$ を代 入することにより求められる ${ }^{91}$.

Fig. 15 に，A，B両タンクの動液圧による初期不整の 変動分を $\varepsilon_{n} a_{0}=1$ として示した. 真円タンクに対し求ま る動液圧計算値の高さ方向平均値を $(D L F)_{n, \theta}$ の算定 に用いている.

Fig. 15 より, 周方向波数 $n=5 \sim 10$ の成分を有する初 期不整の動液圧による変動が大きいことがわかる.また， 動液圧の変動により空時の初期不整の 5 - 8\%の法線方 向変位が生じることになる. Fig. 15 では入力加速度を $100 \mathrm{gal}$ としているが，入力加速度を大きくするにつれ 初期不整の変動量は大きくなる. Fig. 9 に示したように 空時の初期不整は, 側板中央部 $n=3 \sim 8$ で $\varepsilon_{n}=0.001$ 前後となっている. したがって動液圧による初期不整の 変動分は法線方向変位でみるとわずかである. しかし動 液圧が基本振動数 $f_{1}$ で変動しているとすると変位振幅

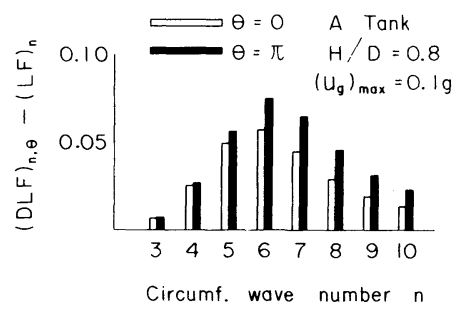

Table 5 Loss Factor of Initial Irregularities due to Static Pressure.

\begin{tabular}{|c|c|c|c|c|c|c|c|}
\hline$n$ & 3 & 4 & 5 & 6 & 7 & 8 & 9 \\
A Tank H/D $=0.8$ & 0.03 & 0.11 & 0.29 & 0.52 & 0.72 & 0.84 & 0.90 \\
B Tank H/D $=0.5$ & 0.01 & 0.03 & 0.07 & 0.16 & 0.30 & 0.47 & 0.62 \\
\hline
\end{tabular}

に $\omega_{1}^{2}=4 \pi^{2} f_{1}^{2}$ 乗じた加速度が生じることになり， $\varepsilon_{n}$ $=0.001$ 亡して $n=3 \sim 8$ の周方向波数のそれぞれにつき $100 \mathrm{gal}$ 前後とかなり大きな法線方向加速度が生じる. また側板中央部の軸方向および周方向の局部曲げ応力 は，それぞれ $(0.005 \sim 0.04) \mathrm{MPa},(0.01 \sim 0.10) \mathrm{MPa}$ となる. 以上のことから側板中央部の法線方向加速度や 側板応力の実測值が真円を仮定した計算值を大きく上 回った理由は，空時の初期不整の周方向高次成分が静液 圧により減少し，さらに動液圧によりその一部が回復も しくはさらに減少したことに主原因があると考えられ る.

壁面初期不整に起因して側板中央部には，かなり大き な法線方向加速度が生じるが，それに伴い生じる応力の 絶対值はそれほど大きなものではなく，かつ座屈に直接 的には関係しない周方向の局所的な曲げ応力が主体であ るので，耐震設計上重要視する必要はそれほどないと考 えられる。

\section{5. 結 論}

本文では，数值計算により弾性基礎上に自由支持され た円筒タンクの側板下端の局部変形によるロッキング振 動および壁面の初期不整が円筒タンクの地震応答挙動に 及ぼす影響について検討を加えるとともに, 模型夕ンク の振動台加振実験を実施し種々の観点から検討を加え た。以下に得られた主な結果を要約して述べる.

（1）実験より得られた固有振動数は, 下部完全固定 の条件を満足できなかった場合の基本振動数が $20 \%$ 程 度小さかった以外, 計算值と全般的によく一致した.

（2）撓性基礎に自由支持された場合，ロッキングに より固有振動数は, 下部固定に比べ大きく減少すること を計算および実験の両面から明らかにした。

（3）地震波加振実験における動液圧や側板下部応力 の実測値は, 下部固定, 自由支持のいずれの場合も真円

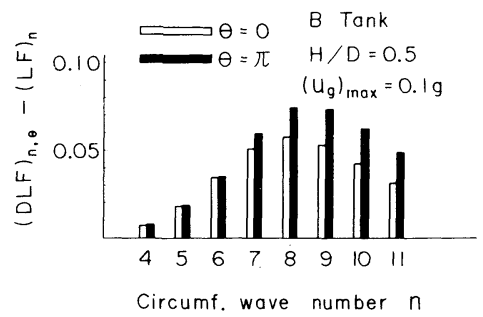

Fig. 15 Radial Displacements produced by The Hydrodynamic Pressure $\left(\varepsilon_{a}=1\right)$. 
タンクに対する計算值とよい対応を示した。

（4）壁面の初期不整が応答挙動に及ぼす影響につい ては, 容器・液間の連成振動の観点からは下部固定で $H / D$ が小さい場合, 側板下端の軸方向膜力が増大する. 実験でも同様のことが確認できた。しかしその増大の程 度は真円夕ンク計算值の 10 ～30\% 程度であり初期不整 のより小さな実タンクでは高々 $10 \%$ 程度と考えられ る.

（5）側板中央の法線方向加速度や表面応力の実測值 は，真円タンクの計算值を大きく上回った。その主原因 は，空時の壁面初期不整の周方向高次成分が静液圧によ り減少し, 動液圧の変動によりそれらが回復もしくはさ らに減少したことによるものと考えられる91.

（6）壁面の初期不整により側板の法線方向加速度は 真円タンクに比べ相当大きくなる場合があるが，側板に 生じる応力はそれほど大きくなく耐震設計上重要視する 必要はないと考えられる.

謝辞：終わりにあたり，加振実験とそのデー夕整 理に協力していただいた (株) 神户製鋼所の樫尾安雄氏, 吉田啓二氏，浜崎義弘氏に深く感謝致します。

\section{参 考 文 献}

1）頭井 洋・新家 徹：ロッキング及びスウェイを考慮し た円筒タンクの耐震解析, 圧力技術, Vol. 20, No. 3, pp. 152 166, 1982.

2）藤田勝久：弾性支持された液体貯蔵円筒タンクの地震応 答解析，機械学会論文集 (C 編)，48 巻 428 号, pp. 516 $\sim 525,1982$.

3）谷 資言・掘 直人・緑川 功：液体の入った円筒シェ ルのロッキング振動解析, 建築学会論文報告集, No. 316,
1982.

4）小林信之・石田和雄：アンカーの無い円筒タンクのロッ キングに対する耐震解析法, 機械学会論文集 ( $\mathrm{A}$ 編), No. 83-0196, pp. 514 519, 1984.

5）頭井 洋・新家 徹：平底円筒タンクの地震時隅底部応 力解析, 圧力技術, Vol.20, No.6, pp. 1 7, 1982.

6) 頭井 洋・新家 徹：底板の浮き上り変形をともなう円 筒夕ンクの地震時変形解析, 構造工学論文集, Vol. $31 \mathrm{~A}$, pp. $537 \sim 550,1985$

7) Clough, R.W., Niwa, A. and Clough, D.P. : Experimental seismic study of cylindrical tanks, Proc. of ASCE, Vol.105, No.ST 12, pp. 2565 2590, 1979.

8) Manas, G.C. and Clough, R.W. : Further study of the earthquake response of a broad cylindrical liquid-storage tank model, UCB/EERC 82/07, 1982.

9) Veletsos, A.S. and Turner, J.W. : Dynamics of out of-round liquid-storage tanks, Proc. of ASCE, Eng. Mech. Div. Spec. Conf. 3rd, pp. 471 474, 1979.

10）頭井 洋・新家 徹：壁面に初期不整を有する円筒夕ン クの地震応答解析, 土木学会論文集, 第 350 号 / I -2, pp. 207 216, 1984.

11）高圧ガス保安協会，振動実験委員会，同専門委員会：鋼 製円筒形貯槽の耐震実験報告（第 1 回) (第 3 回), 高圧 ガス, Vol.21, No.7, pp.1〜11, No. 8, pp.14〜26, No.9, pp. 14 31, 1984 .

12）通産省告示第 515 号：高圧ガス設備等耐震設計基準, 1981.

13）渡辺 丹：設計用模擬地震動に関する研究，建築研究報 告, No. 92, 1981.

14) Niwa, A. : Seismic behavior of tall liquid storage tanks, UCB/EERC 78/04, 1978.

15）本間康之，ほか：初期たわみを有する円筒壳の座屈強度 に対する理論と実験, 圧力技術, Vol. 13, No. 3, pp. 2 7, 1975.

(1985.2.21 • 受付) 